\title{
CHAROPHYTES (CHARALES, CHAROPHYCEAE) FROM NORTH-EASTERN AND CENTRAL EURASIA \\ R.E. Romanov
}

Central Siberian Botanical Garden of the SB RAS, romanov_r_e@ngs.ru

Institute for Water and Environmental Problems of the SB RAS

\begin{abstract}
The current knowledge of charophytes from Russia and Central Asian states has been outlined.
\end{abstract}

At the moment charophyte floras of particular regions of Eurasia are unevenly known. The separate issue of "The identification manual of freshwater algae of the USSR" (Hollerbach, Krassavina, 1983 ) is the key manual for charophytes from huge areas of Russia and Central Asian states. The list of their localities known up to the first third of the twentieth century was compiled by M.M. Hollerbach (1950). The stages for further knowledge of charophytes from the region studied include comprehensive compilations for Uzbekistan and West-Siberian Plain, species lists for Central Asia, Kazakhstan, Northern Kazakhstan, Kyrgyzstan, Russia, Tajikistan, and Turkmenistan (Taubaev, 1970; Kogan, 1973; Shoyakubov, 1979; Sviridenko, 2000; Zhamangara, 2002; Nurashev, 2003; Romanov, 2009; Romanov et al., 2010; Karimova, Turganov, 2012; Romanov, Boboev, 2016; Sviridenko, Sviridenko, 2008; 2016), as well as compilations and lists mainly for administrative divisions of Russia (Fursaev, Eliash, 1937; Zhivoglyad, Krivonosov, 1982; Iljin, 1984; Volobaev 1991; Vekhov, 2000; Papchenkov, 2001; Zhakova, Balashova, 2001; Safonova, 2003; Zhakova, Solovjeva, 2006; Patova et al., 2008; Romanov, Kipriyanova, 2009; Veisberg, Isakova, 2010; Zhakova, 2011; Zhakova, Konechnaya, 2011; Chemeris et al., 2011, 2013, 2015; Klinkova et al., 2012; Blinova, Koistinen, 2013; Klinkova, Zhakova, 2014; Medvedeva, Nikulina, 2014; Romanov, Kopyrina, 2014; Romanov, Nikolaenko, 2014; Romanov, Shilov, 2014; Romanov et al., 2015a,b, 2017a,b; Romanov, Blinova, 2015; Romanov, Volodina, 2015; Romanov, Pechenyuk, 2015; Romanov, 2017; Romanov, Zhamangara, 2017). The lists of species from Central Asia in borders of the states listed included 35 species (Taubaev, 1969, 1970), 37 species (Shoyakubov, 1979; Hollerbach, 1974) and 47 species (Romanov, Boboev, 2016), and for Russia - 44 species (Romanov et al., 2010) and 48 species (Romanov et al., 2015). The aim of this work are detailed study of morphology, distribution and ecology of charophytes from Russia and Central Asia for taxonomy clarification and identification of regional flora features and taxonomic differentiation of the region studied.

Specimens from herbaria ABGI, ALTB, B, BCN, BILAS, BRSU, COI, H, IBIW, IRKU, KEM, KLGU, KPBG, L, LE, LISU, MA, NNSU, NS, PAL, PSK, SARAT, SASY, SYKO, TELA, TMN, UUDE, W, as well as collections by numerous colleagues and the author, digitized specimens from NY (www.macroalgae.org) and some other collections were studied. It allowed critical assessing of existing dataset and using of data mainly confirmed with vouchers.

The 66 species of charophytes (excl. synonyms), i.e. 14\% of world flora are known from Russia and Central Asia (Afghanistan, Kazakhstan, Kyrgyzstan, Tajikistan, Turkmenistan, Uzbekistan). Excluding the misidentifications 63 species (incl. 56 according to the voucher checked) from all extant genera were found in the region studied. To date 58 species are known from Russia (incl. 49 according to the vouchers checked), 7 (6) - from Afghanistan, 42 (29) - from Kazakhstan, 20 (15) from Kyrgyzstan, 10 (7) - from Tajikistan, 16 (12) - from Turkmenistan, 26 (23) - from Uzbekistan. Chara benthamii A. Braun, C. denudata A. Braun, C. inconnexa Allen, C. zeylanica Willd. s.l., Nitella axillaris A. Braun, Tolypella canadensis Sawa, T. hispanica Nordst ex Allen, T. normaniana Nordst. have been found for the first time. 
Twenty one species were described from the territory of study: C. abnormiformis Vilh., C. altaica A. Braun in A. Braun et Nordst., C. arcuatofolia Vilh., C. canescentiformis Hollerb., C. commutata Rupr., C. condensata Rupr., C. dioica Griffith, C. dominii Vilh., C. eremosperma Rupr., C. fischeri Mig., C. glomerulifera Rupr., C. interrupta Rupr., C. karelinii Lessing, C. kirghisorum Lessing, $C$. locuples Hollerb., C. longifurca Rupr., C. sibirica Mig., C. sphagnoides Griffith, C. subspinosa Rupr., C. uzbekistanica Hollerb., C. wallrothii Rupr., but only 8 ones have now accepted as a species. Chara gilliana R.D. Wood nom. nud. and Tolypella aralica Golenkin nom. nud. have been lacking description till now.

Species of Chara L. are the most frequently encountered in the region studied. Chara vulgaris L. and $C$. globularis Thuill. are the most common in north temperate regions and C. vulgaris - in semiarid and arid ones. Both species are generalist in majority of temperate regions of Eurasia. Low species richness, very rare occurrence, no typical of Nitella C. Agardh species are remarkable features of semiarid and arid regions of Russia and Central Asia. It seems to be the same as in Western Asia (Romanov, Barinova, 2016), being in prominent contrast with Southern and Eastern Asia, one of the centers of Nitella species richness (Zaneveld, 1940; Imahori, 1954; Wood, Imahori, 1965; Khan, Sarma, 1984; Han et al., 1994; Sakayama, 2008).

Species composition of the most Russian territory has no species differentiating it with Northern, Western, Central and Southern Europe in a whole. Very low uniqueness of charophyte species composition is characteristic only for the south of Russian Far East and Russian regions neighboring with Central Asia. Three groups of species differing in their distribution range define distinctiveness of charophyte flora of Central Asia and neighboring Russian areas: 1. a single endemic of Central Asia, C. canescentiformis, to date known from two localities only in Kazakhstan and Kyrghyzstan; 2. species with most or large part of their distribution range situated in Central Asia (C. altaica, C. globata Mig., C. dominii, C. fischeri, C. kirghisorum); 3. species with mainly tropical distribution range ( $C$. benthamii A. Braun, $C$. gymnopitys A. Braun, $C$. hydropitys Reich., C. zeylanica, $N$. globulifera Pal), known from single or few localities in the region studied.

The charophyte protection issues are still in an initial stage in the region studied. Nonetheless, some important charophyte areas can be suggested. They are water bodies in deltas of Volga (incl. western semi-steppe ilmens), Ili, Amu Darya and Syr Darya, Lake Balkhash, Lake Issyk Kul and lakes of Southern Ural (mainly Ilmen State Reserve). The species richness increased and significant phytocoenotic role of charophytes are known for these areas but recent data are available for Volga Delta and Southern Ural only.

The uneven regional knowledge of charophytes and no representative collections from selected region constitute one of the main obstacles for this work. But continuous and future cooperation will definitely reduce amount of blank spots. The presence of some species in selected regions or in the whole area of study needs to be confirmed. The clarification of taxonomy for species like $C$. arcuatofolia, C. canescentiformis, $C$. dominii, $C$. fischeri is required. The efforts for outlining of regional taxonomic differentiation, species protection will be obviously successful on the base of more comprehensive dataset. This is pointing towards continuing of the work presented.

The author is very grateful to the curators of the herbaria listed for their encouragement and guidance, many colleagues for long-term fruitful cooperation.

This work was supported by Russian Foundation for Basic Research, project No. 16-04-00931, and partly by projects AAAA-A17-117012610055-3 in agreement with state order for CSBG SB RAS (0312-2016-0005) and state order for IWEP SB RAS according to the research project № 03832016-0003. 